\title{
Empowerment and Local Level Conflict Mediation in Indonesia: A Comparative Analysis of Concepts, Measures, and Project Efficacy ${ }^{1}$
}

\author{
Christopher Gibson \\ Brown University \\ Michael Woolcock \\ World Bank and Harvard University
}

\begin{abstract}
The notion of 'empowerment' has been more often deductively claimed than carefully defined or inductively assessed, by development scholars and practitioners alike. We define and assess empowerment through an in-depth examination of the extent to which a large community development project in rural Indonesia empowers participants (especially members of marginalized groups) through building their capacity to manage local conflict. Although the project induces conflict through its deployment of a competitive bidding process, we argue that, when well implemented, it can also enable otherwise unequal groups to more peacefully, equitably, and effectively engage one another. Using a mixed methods approach, we compare cases from otherwise similar 'treatment' and 'control' villages to shed light on the chief components of villagers' capacity to manage local conflict. We discuss the interdependencies of two major analytical realms - routines of inter-group collaboration, and sources of 'countervailing power'-and their relation to local conflict processes and outcomes.
\end{abstract}

\section{World Bank Policy Research Working Paper 3713, September 2005}

The Policy Research Working Paper Series disseminates the findings of work in progress to encourage the exchange of ideas about development issues. An objective of the series is to get the findings out quickly, even if the presentations are less than fully polished. The papers carry the names of the authors and should be cited accordingly. The findings, interpretations, and conclusions expressed in this paper are entirely those of the authors. They do not necessarily represent the view of the World Bank, its Executive Directors, or the countries they represent. Policy Research Working Papers are available online at http://econ.worldbank.org.

\footnotetext{
${ }^{1}$ This paper is part of a larger study on local level conflict and participatory development projects in Indonesia. For generous financial assistance we are grateful to DfID, AusAID, the Norwegian Trust Fund (Measuring Empowerment Study), and the World Bank's Conflict Prevention and Reconstruction Unit, and Development Economics Vice Presidency (Research Support Budget). Patrick Barron, Claire Smith, Rachael Diprose and Adam Satu were key members of the research team, and played an integral role in developing the ideas explored here. Other field-level researchers provided ideas throughout the study. We are also indebted to Scott Guggenheim and Ruth Alsop for their active support and feedback, and to Dan Biller and Patrick Barron for helpful comments. Address for correspondence: Michael Woolcock, Mailstop MC3-306, 1818 H Street NW, Washington, DC 20433, USA. Email addresses: christopherlgibson@gmail.com, mwoolcock@worldbank.org.
} 


\section{Empowerment and Local Level Conflict Mediation in Indonesia: A Comparative Analysis of Concepts, Measures, and Project Efficacy}

Empowerment - the process of enhancing individual or group capacity to make choices and transform those choices into desired actions and outcomes - is an increasingly familiar term within the World Bank and the development community more broadly. Given broad organizational recognition through the World Development Report 2000/2001, "empowerment" is now found in the documentation of over 1,800 Bank-aided projects. ${ }^{2}$ Its increasing popularity suggests an emerging, shared understanding that marginalized individuals and groups often possess limited influence in shaping decision-making processes that affect their well-being. Still, relatively little reliable empirical work exists to show whether and how Community Driven Development $(\mathrm{CDD})^{3}$ or other projects increase this influence and in so doing, improve development processes and outcomes. ${ }^{4}$ This paper represents one attempt to make headway on these fronts using a mixed methods approach to analyzing local level conflict management spillovers from the Kecamatan Development Program (KDP) in Indonesia.

A key assumption of this paper is that project and country contexts ultimately shape localized manifestations of individual and group power. In the case of KDP, the context is one of a very conscious movement away from the notion of a project as the deliverer of a particular product and towards a notion of projects as a way to trigger and support processes in which villagers exercise discretion in solving self-identified development problems. ${ }^{5}$ Far from merely tweaking incentives for individual involvement in civil society, KDP has systematically opened up the exercise of state-level power to collective decision-making and influence by groups on the local level. A similarly decisive factor in the Indonesian context is the primacy of collective identities in shaping group-based decision-making. ${ }^{6}$ Precisely because of these project and country contexts, KDP's approach to empowerment is distinctly collective. As such, the primary form of power that this study examines - conflict management capacity — is an inherently relational one.

As an example of what Peter Evans has termed collective capabilities ${ }^{7}$, cases of marginalized groups influencing everyday conflicts amount to a kind of "meta-indicator" of empowerment. ${ }^{8}$ We propose that as these processes of resolving everyday conflicts come to mirror the "adaptive problem solving" processes of well-functioning KDP forums, the distribution of conflict

\footnotetext{
${ }^{2}$ Alsop, Heinsohn, and Somma (2004)

${ }^{3}$ Community Drive Development (CDD) is an overarching term used by development agencies to refer to projects that have a high participatory component on the part of beneficiaries, and especially the poor. As such, CDD is a "process that recognizes that poor people are prime actors in the development process, not targets of externally designed poverty reduction efforts" (Gillespie, 2004: 1).

${ }^{4}$ Mansuri and Rao (2004)

${ }^{5}$ Guggenheim (forthcoming)

${ }^{6}$ See Barron and Madden (2003)

${ }^{7}$ Evans (2002). Rao and Walton (2004) similarly develop the concept of "equality of agency" to consider how individual opportunity is influenced by relational social and cultural systems that ultimately impact poverty and inequality.

${ }^{8}$ We do not assume that KDP causes this form of empowerment. Rather, we examine a two-way association between certain KDP practices and conflict management capacity of marginalized groups using a counterfactual which allows us to compare whether or not marginalized groups in KDP treatment villages exert more power in conflicts than do marginalized groups in similar conflicts from comparable control villages.

${ }^{9}$ Heifetz (1994)
} 
management capacity often expands to include women, the poor, and other marginalized identity groups. That is, where marginalized groups use conflicts to generate dense, diverse, and organized collective action, they may also become more capable of exercising meaningful influence in conflict management forums. We explore conditions under which this may (or may not) be the case. A hallmark of this capacity is heightened associational contact between groups in formalized settings as well as a brand of highly discretionary and transaction intensive decision-making ${ }^{10}$, which lends itself to the formation of new, less rigidly bounded prescriptive identity groups.

The paper proceeds in five sections. Section One briefly reviews theories and evidence on conceptualizing empowerment in the context of local conflict. Section Two describes the particular challenges of measuring conflict management capacity and then describes the methodology for doing so in this study, using 72 case studies of local level conflict management in Indonesia. Section Three re-interprets key conceptual and empirical linkages between conflict management capacity and local level power by proposing an analytical framework for the comparative analysis of conflict pathways. Section 4 presents our analysis and results. Section 5 concludes.

\section{Conceptualizing Empowerment: A Review of Theory and Evidence}

Reliable approaches for measuring empowerment must start from a firm conceptual grasp of which actions constitute different kinds of power within particular contexts. This section briefly synthesizes academic and operationally relevant thinking about capability, power, and conflict in development.

Since the publication of Sen's Development as Freedom, a growing tradition within development economics and the social sciences has come to recognize intrinsic as well as instrumental reasons for why and how capabilities matter to development interventions. Sen first popularized the notion that these intrinsic and practical reasons are deeply intertwined: the work of advancing people's basic freedom of capability is simultaneously a means and end of development. Because poverty is a form of "unfreedom" characterized by powerlessness, it is both ethically disconcerting as well as functionally problematic for development institutions. The poor in some very practical sense lack the capabilities required to first develop their interests fully and then devise and choose between options for pursuing them. ${ }^{11}$ Nussbaum further describes the related tendency of marginalized groups to form "adaptive preferences", or narrow practical aspirations that shape how they conceive of their life possibilities. ${ }^{12}$ Her theory demonstrates a key constraint within many popular notions of capability: they de-emphasize the social and cultural systems that shape and develop capabilities.

The study of empowerment stands to capably challenge this tendency toward methodological individualism where it carefully describes how these relational systems encourage and

\footnotetext{
${ }^{10}$ Pritchett and Woolcock (2004)

${ }^{11}$ Sen (1999)

12 Nussbaum's (2000) concept of adaptive preferences has a longer intellectual history, though her work is most closely associated with it.
} 
alternatively discourage marginalized groups from acquiring and exerting the power to make effective choice. As Peter Evans points out, "organized collectives-unions, political parties, village councils, women's groups, etc.- are fundamental to people's capability to choose the lives they have reason to value. They provide an arena for formulating shared values and preferences and instruments for pursuing them, even in the face of powerful opposition." 13 Thus, a key question becomes not so much whether, but how such relational systems influence the development of individual capabilities and particularly choice. Recent work within the World Bank has attempted to describe and explain this association between collective opportunity structures and individual agency, as well as show how it adds up to empowerment in a particular context. ${ }^{14}$ Petesch, Smulovitz and Walton (2005) further suggest that two causal frameworks are required: the first must explain the causes of a form of empowerment, while the second should model the effect of that form of empowerment on certain development outcomes. ${ }^{15}$ (The second question is the subject of a separate program evaluation and is not dealt with here; see instead Barron, Diprose and Woolcock 2005.)

But how are we to go about the first task of constructing a contextualized framework of empowerment itself; that is, of the processes by which members of poor and marginalized groups acquire and exert greater power using group processes over time? Here, recent anthropological theory and evidence provides useful insight. Based on his study of the Mumbai Slum and Shackdwellers Movement, Arjun Appadurai has suggested that a key form of powerlessness for the poor involves living with "negative terms of recognition." A fundamentally relational concept, terms of recognition highlights "the conditions and constraints under which the poor negotiate with the very norms that frame their social lives" such that "the poor are frequently in a position where they are encouraged to subscribe to norms whose social effect is to further diminish their dignity, exacerbate their inequality, and deepen their lack of access to material goods and services." Improving terms of recognition starts with the development of more broadly accessible currencies of associational interaction that ultimately build the "capacity to aspire." As a navigational capacity reciprocally linked to greater voice in associational interactions, the capacity to aspire thrives on practice, repetition, exploration, conjecture, and refutation. ${ }^{17}$ Thus, contextually relevant public actions and performances often serve as a starting point for powerless groups to both express voice via productive conflict with dominant norms as well as to "get recognized" by different and more powerful groups, which might otherwise lack a motivation to acknowledge them at all.

Various models of community-driven development (CDD) and governance have recently arisen as a proposed way to introduce such productive conflict in the hopes of improving the often dismal logic of collective action so familiar within local social institutional settings characterized by elite capture. KDP, for example, proposes to open decision making processes around public

\footnotetext{
${ }^{13}$ Evans (2002: 3)

${ }^{14}$ Alsop, Heinsohn and Somma (2004). Indeed, our study seeks to show how KDP influences the intersection of structure and agency factors in the lives of program participants.

${ }^{15}$ Walton (2003)

${ }^{16}$ Appadurai (2004: 66)

${ }^{17}$ Ray (2003: 7) has cogently argued that the combination of material poverty and a lack of connectedness to groups in shared "cognitive neighborhoods" denies these particular opportunities for associational interaction, causing "aspirations failures." Such failures are caused by "the absence of a critical mass of people who are better off than the person in question yet not so much better off that their economic well-being is thought to be unattainable."
} 
problems to the influence of ordinary citizens, particularly the most marginalized groups in a given setting. A growing body of research on deliberative decision making processes has hypothesized a range of mechanisms by which institutional innovations like those of KDP might empower members of marginalized groups. ${ }^{18}$ They generally agree that closely tying the exercise of public power to active and broad citizen participation can - under certain conditions - expand the influence of disenfranchised groups. Especially when the currency of public exchange and decision-making becomes fairness-based reasoning itself - rather than other more familiar approaches to promoting rigid group interests via mechanisms such as strategic negotiation, command and control by experts, or aggregative voting-weaker voices can more easily be heard. In such cases, socially marginalized groups may develop the tools to influence productive conflicts about the purposeful structuring of future undertakings by newly formed groups. By generating more open and accessible forums for productive, inter-group conflict, deliberative democratic arrangements do not only give marginalized groups a seat at the table with more powerful interests. Importantly, they also codify deliberation itself-and its overarching value of fairness- and reason-based group decision making - as the preferred currency of social exchange, which facilitators and a set of incentives for participation by women and the poor are structured to support.

Yet within KDP and more generally within CDD, little is known about the processes constituting this brand of decision-making and whether they actually accomplish what their creators hope they do. ${ }^{19}$ They are also part of a "black box" question in program evaluation about whether and how deliberative decision making institutions - whose forms necessarily adapt according to the discretion of facilitators and participants in localized contexts - widen influence in decisionmaking processes and generate better project outcomes. ${ }^{20}$ Because expressing voice and improving terms of recognition requires distinctly collective and "processual" 21 actions, they quickly become very difficult to measure as well as likely to be mistaken for the more easily observable static events in which they often culminate. What is known about the processes and outcomes of deliberative processes suggests that they require a different analytical frame than those typically applied to top-down, adversarially oriented institutions (e.g., political parties, labor unions) characterized by conventional interest group politics or social movements. ${ }^{22}$ KDP's arrangements fit what Fung has called the "participatory collaborative" mode of governance: its routines, institutions and norms are largely decentralized, they focus on joint public problem solving, they invite broad public participation, and they occur in a more or less continuous and institutionalized way (as long as the program runs in a given village). As such, one might expect that the forms, functions, and effects of conflict management routines in well functioning collaborative arenas differ substantially from those in adversarial ones. ${ }^{23}$

\footnotetext{
${ }^{18}$ See Cohen and Rogers (1995), Fung and Wright (2003), Hirst (1994), Putnam (2000), and Evans (2004).

${ }^{19}$ Mansuri and Rao (2004)

${ }^{20}$ Whiteside, Woolcock and Briggs (2005) deal with this question more concretely.

${ }^{21}$ Kabeer (1999)

${ }^{22}$ As pointed out in Fung (2002), the logic of politics within a stylized notion of adversarial top-down institutions is well-documented by both political scientists and sociologist. Scholars of collective action, interest group politics (Olson 1965; Wilson 1980), and social movements (McAdam, Tarrow and Tilly 2001; Piven and Cloward 1977) have described how organized interests contest for the power to create or dissolve binding laws or administrative rules typically decided upon through bargaining, implemented by agencies, and administered to stakeholders and the general public.

${ }^{23}$ Fung (2002: 16)
} 
We might also expect substantial qualitative differences between routines shaped by different concentrations and types of group influence. Most obviously, a conflict management routine that emerges from high concentrations of power will generally perpetuate group inequalities, while forms of shared or countervailing power may generate more discretion for marginalized groups. When first introduced by John Kenneth Galbraith, the notion of countervailing power had grown largely out of the analysis of interest group politics in adversarial arenas. It referred to the ability of trade unions, consumer organizations, and other organized interest groups to mold government rules and regulations that kept highly concentrated American industries in check following World War II. ${ }^{24}$ But as Fung and Wright point out, the form of countervailing power underlying successful experiments with participatory collaboration differs substantially from that which evolves in adversarial arenas. ${ }^{25}$ In part, collaborative countervailing power refers to the ability of otherwise disadvantaged groups to instantiate a wholly different kind of rule for group decision making: the principle of fairness itself. The convergence of fairness-based deliberation as a decision rule with collaboration as an institutionalized style of collective decision making discourages the perpetuation of pre-fabricated interests by pre-formed groups and encourages the exploration of joint interests by new, (often) functionally-oriented identity groups. In practice, the rise of such routines partially neutralizes elites' prior advantages in organization, knowledge, intensity of interest, rhetorical capabilities, and agenda-setting ability, thereby diminishing several key tools of exclusion and subjugation. One potential result of this shift is a broader distribution of influence between marginalized and dominant groups. ${ }^{26}$

Thus, two analytically crucial parameters of comparison arise for those interested in understanding the routines governing both local level conflict management and inter-group power relationships: fairness-based versus purely interest-based decision rules and adversarial versus collaborative types of forums. Distinct sources, forms, functions, and effects correspond to distinct combinations of each and determining the qualities of various combinations is the task of empirical analysis. Although the growing literature on participatory collaboration suggests that the most durable forms of empowerment require both countervailing power and collaborative forums, the evidence gathered in this study suggests that such happy combinations are rare indeed. More often, conflict management routines feature one, the other, or neither.

If conflict management routines constitute a key realm of analysis for those interested in understanding local level empowerment, they provide little leeway for making causal statements either among their constituent parts or between them and outcomes. ${ }^{27}$ On one hand different local institutions and rule systems are products of fundamentally distinct ontologies - and thus

\footnotetext{
${ }^{24}$ Galbraith (1956)

${ }^{25}$ Fung and Wright (2003: 266)

${ }^{26}$ Fung (2002: 19)

${ }^{27}$ Consider the Wittgenstein problem, which asks what relationship exists between a rule and its interpretation. Routines might be thought of as the link between the two: the guidelines and suggested modes of communications for deciding when and how a rule applies. While all development interventions by nature introduce rules that are likely to clash with other pre-existing rule systems, not all development projects propose the same routines for working out that inevitable conflict. Well functioning CDD forums provide a distinctive contribution by creating resources, incentives, and associational spaces as well as a set of collaborative (rather than adversarial) routines for managing conflict. Collaborative routines have greater promise to generate shared domains of meaning, while adversarial routines threaten to generate "loyalty" or "exit" approaches to conflict management.
} 
frame whether and how members of marginalized groups develop individual agency. Collaborative forums encourage routines of speaking, acting, and group decision making with which more and less powerful groups define, defend, and represent their interests with less of an orientation toward niche preservation and more of an orientation toward exploring shared preferences. Where forums encourage identity groups to recognize other identity groups in shared social space as potential allies rather than enemies, the potential for marginalized individuals to form coalitions and to begin acting collectively and with more influence ultimately rises. On the other hand, concluding that collaborative forums generate countervailing poweror vise-versa-imposes a very high burden of proof, one that even the most high-quality empirical exploration is unlikely to generate.

Nevertheless, both theory and empirical observation reveal that marginalized groups often wield little clout, suffer from unstable preferences, and may be unaccustomed to confidently representing their preferences in formal associational settings. Without tools of speaking and acting in such settings, they inevitably struggle to be taken seriously by actors who have mastered (and indeed may have invented) dominant norms and rules of interaction. To counter this inherent disadvantage, to avoid being exploited, and to establish collaboration as the preferred norm of interaction within a forum, marginalized groups have to fill the power vacuum with demonstrable proof of their particular abilities. Such an undertaking often requires the transformation of what James Scott calls metis ${ }^{28}$ - idiosyncratic contextual knowledge of local cultural and social circumstances - into discursive and practical performances that engage more powerful groups in cultural languages in which the poor possess some comparative advantage. ${ }^{29}$

These notions of countervailing power and collaborative routines of conflict management may initially sound too esoteric to be operationally relevant or measurable. Nevertheless, they are a pivotal feature of what project creators allude to when they hypothesize that CDD forums trigger and support processes in which villagers exercise discretion in solving self-identified development problems. ${ }^{30}$ As one slightly more observable manifestation of the "terms of recognition" defining power relationships between conflicting groups, a broad range of routines drive various types and stages of conflicts occurring both within and outside of KDP forums. Drawing comparisons across the two simultaneously helps us trace what contributes to effective conflict management and describes what institutional features empower marginalized groups in the course of conflicts. As such, understanding the processes and outcomes of conflicts demands a clearer understanding of the forms, functions, processes, and results of these routines as well as the countervailing power dynamics that accompany them. We next discuss a case-based methodological approach to analyzing routines and types of power in local conflicts.

\footnotetext{
${ }^{28}$ Scott (1998: 311) argues that 'mētis', a Greek concept, is useful as "a means of comparing the forms of knowledge embedded in local experience with the more general, abstract knowledge deployed by the state and its technical agencies." For Scott, "mētis seems to better convey the sorts of practical skills that I have in mind than do such plausible alternatives as "indigenous technical knowledge," "folk wisdom," "practical skills", techne, and so on" (p. 313).

${ }^{29}$ Such tactics might be thought of as conflict-specific "weapons of the weak," in the way that Scott (1985) discusses them. Similarly, these actions can be thought of as distinct forms of exercising and leveraging what Pierre Bourdieu (1986) calls "cultural capital", or context-specific knowledge and behavior.

${ }^{30}$ Guggenheim (forthcoming)
} 


\section{Measuring Empowerment: An Applied Method}

This section first briefly summarizes the overarching study questions, hypotheses, and research design for collecting data on dynamic conflicts and constructing conflict pathways case studies. Then it describes the comparative methodological approach taken in analyzing the conflict pathways case studies in a way that unpacks local level power relationships in each.

The larger study for which this data was collected - the KDP and Community Conflict Negotiation Study - is partly an assessment of the impact of the Kecamatan Development Program (KDP) on communities' ability to manage local conflict. While KDP was by no means designed as a conflict resolution program, the core question of the study is whether or not KDP builds the conflict management capacity of villagers through unexpected spillovers from the deliberative processes it initiates. Begun in 1998, KDP is a massive community development project, the largest in Southeast Asia, operating in over 28,000 villages ( $40 \%$ of the total) across Indonesia. KDP distributes US\$60,000-\$110,000 block grants directly to kecamatan (subdistricts) and ultimately to villages for almost anything villagers themselves feel is a development priority, typically small-scale infrastructure, social, and economic activities. We propose that in addition to KDP's complaints mechanisms, a key process by which KDP aims to alleviate poverty and improve local governance-convening a series of facilitated forums/meetings at the hamlet, village, and kecamatan level to encourage and institutionalize broader community participation in decision-making and priority-setting ${ }^{31}$-might also incrementally shift power relations on local levels.

The study has generated some evidence supporting core hypotheses about these processes: that KDP's socialization, planning, decision-making and implementation processes both improve the deliberative skills of community groups as well as build trust between these groups by forging associational ties. ${ }^{32}$ To test this and other hypotheses about KDP, the research generated over 70 "conflict pathways case studies", that is, ethnographies of how particular social tensions and incidents of conflict played out in their local context. Researchers wrote these case studies based on over 800 focus group discussions, in-depth interviews, and participant observations that they conducted. This approach permitted researchers to establish ongoing conflicts as the primary unit of analysis to be studied. Thus, each examines how different actors-villagers, facilitators,

\footnotetext{
${ }^{31}$ For more details see Guggenheim (forthcoming), KDP National Secretariat (2003), and Barron, Diprose and Woolcock (2005). KDP works as follows: villagers develop proposal suggestions at facilitated meetings at the hamlet level (musbangdus) and then take them to a village meeting (musbangdes), where the community democratically decides which two proposals are most worthy to be discussed at the kecamatan meeting (MAD Musyawarah Antar Desa). At the kecamatan meeting, delegations (which must consist of at least two women and one man) present their proposals and together decide on which proposals will be funded. Since KDP purposefully does not fund all proposals this forum produces vigorous negotiations among and between different groups of villagers. A large network of facilitators help to socialize the program, organize the meetings, link the community with outside assistance if necessary, and ensure project implementation runs smoothly. In each KDP village two elected village facilitators (FDs) introduce the project to village institutions. At the sub-district level, one appointed facilitator (FK) focuses on social issues, while the other FK attends to technical matters. Because FKs have institutional backing but are relatively independent of local power structures, they are well-placed to trouble-shoot and facilitate problems that may arise. Once the proposals are selected after 6-8 months, each successful village elects an Activities Implementation Team (TPK), and the villages together form a Financial Management Team (UPK) for the entire kecamatan.

${ }^{32}$ See Barron and Diprose (2004)
} 
local leaders, etc.- - together manage (or fail to manage) different types of conflict in different settings. Using a version of case-based process tracing (George and Bennett 2005, Varshney 2002), conflict pathways describe discrete stages in the evolution of conflict including conflict triggers and factors or mechanisms that sustain conflict, allow it either to escalate, stagnate, or move toward resolution. By following cases of everyday conflict, the factors that transform underlying tensions into different outcomes - violence or peace-become evident. In essence, the cases work backwards from an outcome by asking what led to what. Importantly, they were selected in a way that controls for some of the traditional weaknesses of qualitative approaches ${ }^{33}$ while capturing each stage of a conflict, attempts at its resolution, and events that linked different stages. Each case study includes a summary of the case, its "pre-history," evolution, attempts at resolution, impacts, and aftermath.

Figure 1

District and Sub-district Qualitative Sampling Frame ${ }^{34}$
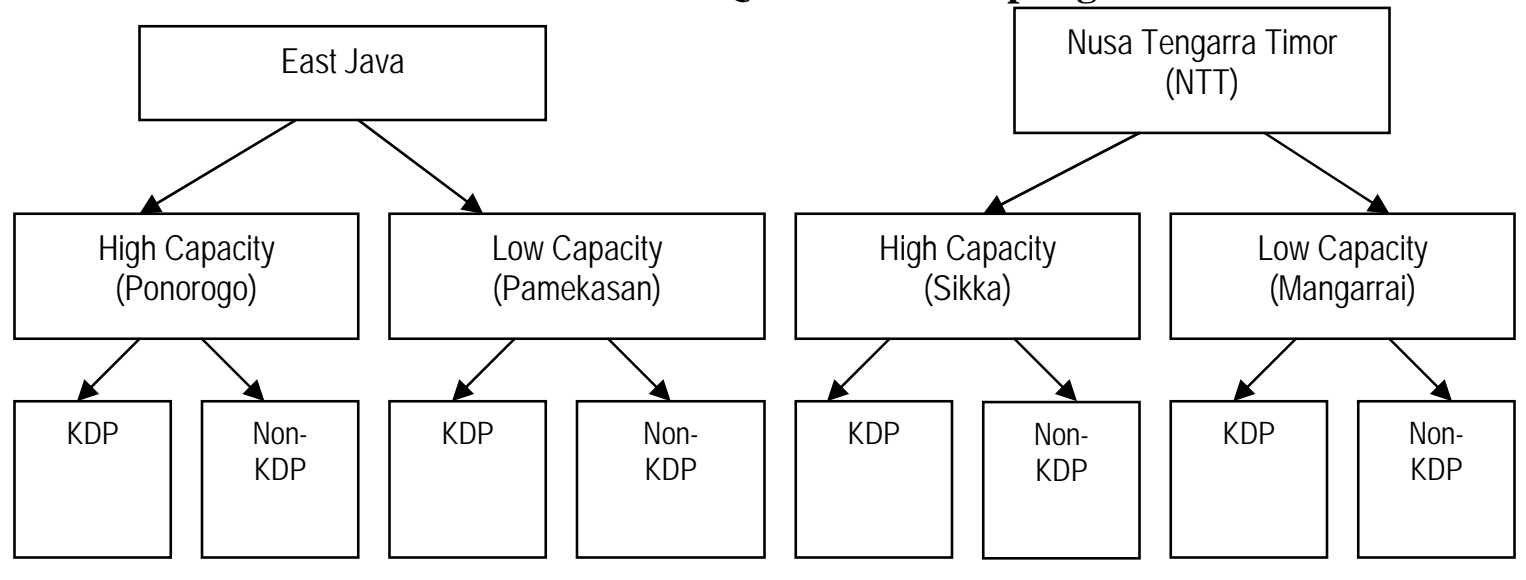

Collection of the qualitative data used to construct these cases occurred in three stages and used a quantitatively oriented sampling frame in order to construct a plausible counterfactual. Propensity score matching 35 was used to "match" villages that received KDP with those that would have been likely to receive it but did not, further verified by qualitative interviews to

\footnotetext{
${ }^{33}$ See Barron, et al (2004) for a more detailed description of the sampling methodology.

${ }^{34}$ For more detailed information on how this sampling framework applied across three distinct stages of research, see Barron et al (2004).

${ }^{35}$ The propensity score is a statistical measure designed to calculate the probability of a given household or village being selected for inclusion in a program (for an introduction, see Baker 2000). The score was estimated using the PODES (1996) dataset. (PODES, which stands for Pontesi Desa (Village Potential), is a key informant survey administered every two years by BPS that contains information on each of 60,000 plus villages in Indonesia.) The actual propensity score was derived using explanatory variables that could serve as proxies for the economic level of the kecamatan. Among the PODES variables used were: population, access to urban facilities such as markets, hospitals, department stores, health and education resources, main source of income, perception of poverty level, etc. These are all 'observable' factors, however, so to control for 'unobservable' factors (e.g., motivation, cohesion, leadership) we used the propensity score to select three statistically comparable non-KDP ('control') villages and then asked our field research team to identify which of these was, in their view, the most appropriate match for the KDP ('treatment') village.
} 
confirm the accuracy of those statistical matches. ${ }^{36}$ To control for endogenous factors contributing to conflict management, matching of villages was conducted within districts with high and low capacities for conflict management (see Figure 1). ${ }^{37}$ Within both high and low capacity districts, we constructed a counterfactual that permits meaningful comparisons between: (a) cases of conflict from "treatment" villages in which KDP operated for at least three years and (we hypothesize) influenced conflict processes and outcomes; and (b) similar cases from "control" villages which would have been statistically likely to receive KDP but have not. After conducting pre-fieldwork and devising this sampling strategy in this first stage of the research, we applied it in two stages of fieldwork.

Stage 2 of the research exploited these treatment and control groups to assess conflict management spillovers from KDP processes onto everyday conflicts unrelated to KDP. This approach permits exploration of correlations between (rather than strong causal statements about) KDP's treatments and the presence or absence of capacity to manage such conflicts. Perhaps more importantly, construction of these comparison groups permits observation of "baseline" political, cultural, and social contexts as well as the conflict management routines that characterize conflict pathways in treatment control villages. In practice, Stage 2 cases prove especially useful for studying power relationships in the absence of KDP interventions. They permit detailed analysis of the conditions under which marginalized groups of villagers do and do not gain access and exert influence in the courses of everyday local conflicts.

Stage 3 more directly examined conflict pathways within KDP processes themselves and permitted comparisons between them and the counterfactual of conflicts that arose in other development projects in similar villages. These cases lend a slightly more powerful lens for examining claims about the "empowerment" value of KDP, specifically whether (or not) and how (or how not) the "treatment" of KDP permits marginalized groups to express voice, influence decision making, or to more capably manage collective conflicts that affect their lives. "Treatment" refers to the spaces, incentives, and resources that — when functioning properlyKDP introduces on neighborhood, village, and sub-district levels. By comparing these cases to similar conflict pathways that emerged out of other village level development projects in similar villages at roughly the same time, we begin to isolate whether and how marginalized groups who participate in KDP's inevitable conflicts also build what we shall call the capacity to engage. Throughout, however, we highlight the process (not the outcome features of programmatic treatments).

In addition to using the comparison groups set up by Stages 2 and 3, we further disaggregate each group into five types of everyday conflicts in our research areas: publicly administered projects, elected office-seeking, domestic violence, vigilantism, and contested natural and human made resources. Though the analytical lines distinguishing these types are somewhat fluid, we have nevertheless tried to make comparisons within (rather than between) these types in order to ensure that the conflicts being compared at least begin with similar sets of motivations of the

\footnotetext{
${ }^{36}$ Thereby helping to control for unobserved variables, which propensity score matching techniques alone cannot.

${ }^{37}$ Research teams made the determination about high and low capacity districts through extensive consultations at the provincial level with government, international and local NGOs, regional development experts, universities, and KDP staff. See Barron, Diprose, Madden, Smith, and Woolcock (2004) for further details.
} 
actors and groups involved. Previous research from our research districts ${ }^{38}$ and pre-fieldwork suggested three criteria for constructing this typology: underlying social tensions, number, and types of actors involved at the initial stage of conflict. All these criteria apply to the initial (temporal) stages of a conflict because subsequent changes in the types, numbers of actors, and underlying tensions reflect precisely the desired variation in group motivations, interests, and identities, which constitute conflict management routines.

Because each case also describes the forums and social institutions used in the management (or mismanagement) of these different conflict types, conflict pathways also represent rich sources of data on the intra- and inter-group power relationships within a given local context. More than mere series of static disputes over particular issues, dynamic conflict pathways represent distinctive, self-contained phenomena which develop their own momentum and have a life of their own. As they evolve, they propose their own sets of practical and discursive routines, which become the tools that more and less powerful groups use to parse out their internal and external differences in more and less equitable ways. Next, we discuss some key concepts for drawing out these differences in representative cases.

\section{Assessing Empowerment: Indonesian Case Studies}

In this section, we first develop the chief concepts we use for assessing conflict management routines and then summarize some representative cases studies of conflict pathways. Although the study defines and tracks 5 basic types of conflict case studies-political office-seeking, vigilantism, domestic violence, contested public resources, and publicly administered projects $(\mathrm{KDP} \text { and non-KDP })^{39}$-we observe a dizzying amount of variation within cases of the same type, even when the villages from which they come are in the same sub-district. Partly because of substantial diversity in cultural histories and ethno-linguistic orientation within each of our two research districts, a broad range of institutions, norms, individual and collective capabilities molds conflicts, their management or mismanagement, and ultimately the influence that marginalized groups exert in them.

To draw meaningful comparisons across these many levels of heterogeneity, we first propose, as Heifetz and others ${ }^{40}$ have argued, that local level conflict management poses a fundamentally "adaptive" rather than "technical" challenge to villagers and marginalized groups (as well as to agencies which aim to structure effective local level development interventions). That is, constructive solutions to conflict require contextually specific collaboration of a type that can rarely be determined ex-ante by outside technocrats. Successful interventions turn on the creation of spaces, incentives, and resources needed to make it possible for disputants to craft resolutions that all sides can own, uphold, and enforce. Encouraging nonviolence and conflict management in situations characterized by numerous (and potentially competing) understandings of justice is unlikely to be achieved with uniform technocratic "policies" or standardized "programs." Rather, it fundamentally relies on transaction intensive and highly discretionary "practices" that arise from myriad face-to-face encounters between actors. The presence and use

\footnotetext{
${ }^{38}$ See Barron and Madden (2002) and Smith (2004)

${ }^{39}$ These conflict categories come from Diprose (2004).

${ }^{40}$ See Heifetz (1994), Pritchett and Woolcock (2004), Fukuyama (2004).
} 
of such conflict management practices may make the difference between everyday disagreements (e.g. agricultural theft, political tensions) erupting into violence instead of ending with more peaceful resolutions. ${ }^{41}$ Though not explicitly designed as a conflict management tool or intervention, KDP's design aims to build the sorts of deliberative skills and collaborative decision making spaces which characterize adaptive problem solving. ${ }^{42}$

On another level, deliberative development projects might be thought of as purposefully introducing routines of inter-group engagement in contexts of inequity. At their best, they provide members of marginalized groups with more than just a disembodied knowledge of their right to participate in and gain influence to decision making forums that they previously lacked, but also with an experienced affirmation of that right by more powerful groups and neutral facilitators. By creating precedents for future, potentially more equitable encounters, such routines may alter the "cognitive neighborhoods" 43 in which a given member of a marginalized group resides, such that engagement with more powerful actors in an associational context becomes more conceivable and attainable. Thus, inter-group decision making that falls short of becoming genuinely collaborative should not be immediately dismissed as just passive access. When repeated, such encounters might also raise expectations among disempowered groups that future such encounters could bring them more influence. The empirical task of identifying and explaining such shifts, however, presents substantial barriers beginning with understanding the inevitable asymmetries that disparate groups bring to processes of deliberation.

As Fung and Wright (2001) and others ${ }^{44}$ have noted, dominant actors typically enter even the fairest processes of deliberative decision making with distinct advantages, including superior intra-group organization, favorable information asymmetries, rhetorical capacities, agendasetting ability, and the discursive ability to de-emphasize input given by weaker and less organized groups. By themselves, collaborative arenas are insufficient tools for nullifying these advantages, which elites have typically honed in more adversarial arenas governed by the logic of rigid interest group maximization. Entering deliberative spaces with this brand of negative "terms of recognition" relative to more established actors (e.g., male village heads) ultimately presents relatively weaker groups (e.g., widows) with a particular dilemma. On one hand, a first time invitation to a KDP forum often attracts ambitious, energetic, and hard-working participants from marginalized groups. On the other hand, in the initial power vacuum of a carefully crafted deliberative space, the familiar discursive routines that such group members typically use to engage one another may hinder their ability to purposefully engage different, more powerful groups. Despite their (often unprecedented) achievement of convening members of more and

\footnotetext{
${ }^{41}$ Barron, Smith, and Woolcock (2004)

42 "Creating effective spaces for deliberation and choice is, in essence, what participatory development projects, at their best, help facilitate. KDP for example generates the mechanisms through which decisions are made in the project, at the village and the sub-district levels, and offers new, relatively neutral inter-group forums within which villagers are potentially able to more peacefully mediate conflicts of certain types. The incentives for different groups and conflicting parties to work together in these forums is the end product of a development project - a savings and loan opportunity, a new road, or a new well. The role of project facilitators is also essential in aiding successful conflict mediation between rival or competing groups, as they effectively act as third party mediators, with a combination of neutrality, technical and local knowledge, willingness and financial resources to help mediate conflicts, which local officials, the police and other institutions may not necessarily possess." (Barron, Smith and Woolcock, 2004)

${ }^{43}$ Ray (2003)

${ }^{44}$ See Scott (1985), Mosse (2004), Fung (2002)
} 
less powerful identity groups in the context of relatively open public decision-making, even the best functioning KDP treatments struggle to rectify these discursive inequities.

But if anecdotal evidence suggests that in this regard, incremental progress is accompanied by high quality facilitators, open deliberative spaces, carefully enforced inclusion mechanisms, and complaints mechanisms, we don't know why this might be the case. Relatively little is known about the linkage, if any, between greater discursive parity and KDP treatments. While much is known about the mechanisms by which collapsed program incentives and failed facilitation predictably harden local power inequities, little is known empirically about whether and how well-executed interventions render them more plastic. If the absence of good facilitation and deliberative spaces stifles tangible routines for contesting and neutralizing the tactical advantages of more established and organized actors, what exactly can their presence accomplish (and what can they not accomplish)? If we know that elites maintain their decision making power by deploying the same old adversarial tactics in putatively collaborative spaces ${ }^{45}$, it is empirically unclear how the reverse occurs.

A superficial overview of the data suggests that when faced with these inter-group disadvantages, marginalized groups acquire influence more by reinventing routines of intragroup organization, interest definition, and interaction than by merely adopting enforced and incompatible sets of the same from stronger groups. Weaker actors often enter conflicts relatively unable to generate the kinds of shared meanings with more powerful actors, which ultimately broaden accountability in group decision making. And collaborative forums do not by themselves provide sufficient means for developing this capability: the introduction of collaborative procedures, rules, spaces, and incentives for inter-group decision-making are necessary but insufficient conditions for building influence. Marginalized groups must also develop the countervailing power they need to credibly maintain a presence at collaborative decision making tables with traditionally more dominant actors.

Recent theory and evidence on collaboration points to one relatively abstract but nonetheless pivotal source of countervailing power familiar to students of social movements: the cognitive frames that more and less powerful groups use to diagnose joint problems, consider potential approaches to their solution, and devise reasons for solving them in the first place. ${ }^{46}$ In short, the different stories that any given group tells to itself and to other groups about a shared problem matters to the nature and extent of interventions likely to generate the rare combination of countervailing power and collaboration. Intra-group, neighborhood level brainstorming and design of project proposals represents KDP's intended compliment to these deficiencies of freestanding collaborative forums.

It is clear, nevertheless, that some of the most highly functioning KDP forums failed to generate the kinds and sources of countervailing power which marginalized groups ultimately require to

\footnotetext{
${ }^{45}$ Indeed a key tactic of powerful groups in deliberative forums is to undermine collaboration if it threatens the advantages they enjoy under a certain distributive and adversarial logic of conflict. Similarly, marginalized groups often use adversarial routines, too, if it helps them gain concessions from dominant groups. Overall, however, adversarial approaches at best might modify the occupants of fixed social stations without changing the structure or logic of that context.

${ }^{46}$ Fung and Wright (2003: 282), Unger (1998: 11).
} 
influence decisions within these newly accessible decision making spaces. Furthermore, even where CDD facilitates the rise and entry of countervailing voices, the sources of strength and sustainability of those voices is largely separate from the shape of collaborative institutions themselves. In short, if CDD opens the door, marginalized groups must be able to walk in more or less under their own strength. And once inside, they must also become capable of expressing their preferences in a way that encourages the collaborative engagement of elites, who are otherwise likely to exert their asymmetric and superior capabilities, prior organization, knowledge, and intensity of interest to dominate decision-making in their favor.

This is all to say that even the most well functioning KDP processes are simply not sufficient to dramatically or monolithically reverse power inequalities on local levels (nor did their creators and greatest proponents propose they would). Rather, the spaces, resources, and incentives it creates encourage the sorts of collaborative routines, which over surprisingly short periods of time can help to incrementally level the playing field between weak and strong actors. For example, high quality facilitators can help weaker groups work together in intra-group brainstorming and developing project proposals on the neighborhood and village level. The competitive process of representing such proposals on the sub-district level in inter-group forums often provides an unprecedented chance for them to "get recognized", both literally with funding and symbolically by earning notice, consideration, and support for their ideas. ${ }^{47}$ In short, the evidence suggests that where KDP initiates processes of inter-group collaboration, weaker groups can often find new footholds of intra-group power in village life. But often these footholds come in the very modest form of modified routines of contestation and refutation (to use Appadurai's language), which may be used to challenge elite dominance within village level decision making processes over longer periods. ${ }^{48}$

\section{Comparative Case Studies Considered}

Although the study used these concepts to explain several types of cases - including many totally unrelated to KDP - the most useful cases for unpacking empowerment are necessarily those that discuss the interventions of KDP itself. All of these comparison groups permit us to examine different types of conflict management routines, or the qualities of inter-group power relationships and decision making forums that arise when underlying social tensions find observable discursive and active expressions.

The first group compares routines from non KDP related conflicts in "control" villages to routines from other non KDP related conflicts in other "control" villages. We use this group to tease out variations in the types of forums and styles of inter-group interaction that occur in everyday village life. These comparisons establish a kind of baseline for how conflicts and local level power relationships evolve in the absence of KDP.

\footnotetext{
${ }^{47}$ These competitive processes can of course also negatively impact weaker groups, especially when their proposals find no little or support (see Barron, Diprose and Woolcock 2005).

${ }^{48}$ Thus, we are not saying that KDP provides a magic elixir enabling the poor to transform such piecemeal footholds into major tactical advantages, nor are we saying that it necessarily transforms adversarial relationships between groups into collaborative ones. Often these footholds come as much in the form of program mechanisms for challenging elite domination as they do in actual face-to-face encounters within forums. For example, an anonymous complaints mechanism in Kecamatan Proppo led to the replacement of a program facilitator who was illegally (by KDP rules) appointed rather than elected.
} 
The second group compares routines from KDP related conflicts in "treatment" villages to routines from non KDP related conflicts in other "treatment" villages. In these cases we can observe the more direct "treatments" of KDP on conflict management capacity, for example whether KDP facilitators, financial and technical advisors succeed in opening conflicts over development projects to the influence of weaker actors. We use this group to explore whether or not the organizing concepts for KDP related conflicts are associated with different routines than the organizing concepts of conflicts not directly triggered by KDP processes themselves.

The third group compares routines from non KDP related conflicts in "treatment" villages to routines from non KDP related conflicts in "control" villages. We use this group to most closely approximate the spillover effect of KDP processes relative to the counterfactual of other development projects. In particular we can examine whether KDP facilitators, technical facilitators, program rules promoting transparency and accountability, and other "treatments" of the program alter local level power relations.

\subsection{State-owned Resources in Kecamatan Badegan, Kabupatan Ponorogo, East Java}

In one case from the KDP village of Biting in Ponorogo, East Java, an extended conflict over the repair of a leaky dam served as a flashpoint for the organization of farmers and other villagers dependent on its empty reservoir for irrigation. Toward the beginning of the conflict, the group mostly used bureaucratic channels to request repairs of the Sumorobangun Dam. After writing a series of letters to the District Legislative Assembly (DPRD) Head and the District Head starting in 1996, the farmers group felt their demands for action had fallen upon deaf ears and began expressing their sense of rejection and anger destructively. As farmers suffered more and more from the water scarcity, frequent arguments and limited small scale violence broke out, including a hoe fight between two family members that resulted in head injuries but no deaths.

As unrest peaked in 2001, the farmers group changed its tactics. In organizing a public demonstration, the group mobilized a broad web of social networks that included teachers, police, civil servants, rice paddy owners/farmers, and paddy workers from four sub-districts. This mobilization caught the attention of a candidate from a locally weak political party who was running for a DPRD seat and took the opportunity to apply pressure on the incumbent. Together, hundreds of villagers blockaded a key road connecting two districts and in the middle of the road set up two chairs facing the dilapidated dam. By demanding that the two officials view the condition of the dam and witness the hundreds of villagers demanding its repair, the farmers group finally solicited a response. The DPRD Deputy Head arrived on the scene and committed to fixing the dam, a promise the district government ultimately fulfilled one year later. Additionally, a subsequent flurry of peaceful and fruitful activism ensued surrounding government compensation for lands previously inundated by the dam. These groups used the conflict to develop new, more effective routines for promoting their interests from below.

In this case, the farmers group actually channeled protracted and escalating conflict into a solidaristic routine of speaking and acting that generated iterative results. On the one hand, appealing to a broad group of protestors generated significant negotiating power for the farmers because while the DPRD incumbent and his challenger could afford to ignore one demographic 
slice of the sub-district, both had a clear incentive to respond to the broader spectrum and more sizable numbers of potential voters who protested. On the other hand, the farmers' use of the richly symbolic protest action of blocking a road with a crowd of villagers and two empty chairs was a public performance that transformed their new association into a powerful force to be reckoned with. To use Appadurai's language, the protest group improved their own terms of recognition relative to more powerful public decision makers.

\section{Box 1. The Ruin of the Sumorobangun Dam Incites Community Reaction*}

"Water has been difficult to obtain since the Sumorobangun dam was damaged. It has been damaged for more than ten years... In the beginning, the dam was built in the seventies and then experienced damage. Then in around 1987 the dam was rebuilt with [Rp] 300 million in funding, but it did not last long. There was lots of corruption, parts of the concrete had holes in them and the ratio of cement in the mixture was too low, so that the first time it rained the steel in the structure was visible immediately, and the stones fell out one by one. When the big rains came the dam subsided. The dam only lasted for two years, more or less, and after that it did not function at all... In fact the village community knew that the quality of the construction was very poor.

Male villager, Dusun Kroyo, Desa Badegan, 24 June $2003^{49}$

“...The dam was rebuilt before, but it wasn't a year before it was full of holes again. The structure had holes in it on the inside, once it was hit by water it was full of holes..."

Male Head of the Stoneworkers group in Desa Badegan, 26 June $2003^{50}$

"In the end, yes, it's been ruined for five years or more. It's been reported several times, but the reports go ignored..."

Female villager, Dusun Badegan, Desa Badegan, 20 June $2003^{51}$

“... I forget which year, a group of farmers from Badegan sent a letter to the Ponorogo DPRD (Dewan Perwakilan Rakyat Dearah, District Legislative Assembly) so that they would look at the damage to the dam, and to ask the Bupati to rebuild the Sumorobangun Dam right away... The farming group is not just made up of farmers! There are also civil servants like myself who farm as well, who joined in with the farming group. There are teachers, police, all kinds of professions, the point is that if they live here and own rice paddies, they are also members of the farming group... The letter did not receive a response for a long time, in the end it was around the end of 2001 when the farming groups from four kecamatan held a demonstration by closing the road leading to the Sumorobangun dam..."

Kecamatan Badegan Civil Servant, 29 June $2003^{52}$

“...I once coordinated the populace from four kecamatan, namely Badegan, Sampung, Jambon,

\footnotetext{
49 .ibid.

${ }^{50}$.See Interview 819 with Head of the Stoneworkers group in Desa Badegan, 26 June 2003.

${ }^{51}$.See Interview 805 with Women villagers, Dusun Badegan, Desa Badegan, 20 June 2003.

${ }^{52}$.See Interview 827, op. cit, 29 June 2003.
} 
and Kauman to hold a demonstration demanding the rebuilding of the Sumorobangun Dam in Biting, by closing the road to the bridge ${ }^{53}$ The mob numbered between 2000 and 3000 people ${ }^{54} \ldots$ in fact I had prepared two chairs on the bridge facing towards the dam for the Bupati and the DPRD Ponorogo Head... so that the district government would know about the problems at the lower level, so that they wouldn't just prioritize development in city... The community was angry because the construction of the Sumorobangun Dam had not been realized, and the people of four kecamatan were tired of working to repair the dam because every rainy season it would just form holes again...The people's demo was very effective, they held the demonstration at the end of 2001 , and now the regional government has realized the construction of the dam..."

$$
\text { Golkar [political party] Badegan Branch Head, } 24 \text { June } 2003^{55}
$$

“...In short, the street was packed, so that it was blocked off... Purwanroro buses could not get past... The DPRD came, yeah, it's called dialogue. It was only after the dialogue that people dispersed...

Midwife living in Dusun Badegan, Desa Badegan, 20 June 2003

“...During the demo, the Deputy Bupati Head and the DPRD Head came, because the Bupati was very busy. The Deputy Head and the DPRD promised Rp. 600 million in funds from local revenue to realize the dam... the promise was made in front of the demonstrators..."

Kecamatan Badegan Civil Servant, 29 June $2003^{57}$

*Names of respondents have been omitted to protect their anonymity and the confidentiality of their responses.

The Sumorobangun Dam case illustrates how a coalition of marginalized villagers revised the dominant practical and discursive routines for managing an ongoing conflict. By using a highly symbolic language of public protest, they exposed shared interests between natural allies, whose commonalities had previously gone unrecognized or unused. Because members of groups inevitably possess multiple roles and identities in a given social context, their choices about which role to play at any given point matters to the level of influence any one might acquire at different junctures. We argue that transformative and solidaristic routines - ranging from patterns of protest action and symbolic performance to patterns of argument within KDP-style forums - often constitute key mechanisms by which marginalized groups expand their influence in this and other ways.

The dam case was a telling example of a locally organized coalition of marginalized groups mobilizing around an issue at a strategic time and with highly innovative discursive and practical tactics that more powerful authorities could not ignore. Whereas numerous attempts to persuade officials to fix the dam using conventional tactics - letter writing, personal lobbying, and formal complaints to public authorities - ultimately failed, the 2001 protest, which followed three years of KDP in Biting, succeeded for a number of reasons. For one, they generated new, highly

\footnotetext{
${ }^{53}$ Another informant said that the demonstration was coordinated by the Watubonang village head; see interview 848, op cit, 20 July 2003. Another informant said that the demonstration did not fully close the main road; see Interview 821, with a female villager, Dusun Badegan, Desa Badegan, 27 June 2003.

${ }^{54}$ Several other informants said that the demonstrators only numbered around 500 people, not thousands. See for example Interview 821, with a female villager, Dusun Badegan, Desa Badegan, 27 June 2003.

${ }^{55}$ See Interview 817, op.cit, 24 June 2003.

${ }^{56}$ See Interview 805 Women villagers, Dusun Badegan, Desa Badegan, 20 June 2003.

${ }^{57}$ See Interview 827 op.cit, 29 June 2003.
} 
symbolic norms that established weaker and traditionally less organized groups as capable of challenging the dominance of sub-district authorities around a certain issue. It would be unwarranted to suggest an indisputable causal link between KDP processes in the village and the development of a new politics of symbolic conjecture, critique, and challenge. Nevertheless, multiple villager accounts of Biting suggest that its thick associational networks - of the kind that KDP's forums aims to create in optimal circumstances - cut across villagers from different socio-economic backgrounds and were more easily mobilized than in comparable, non-KDP villages with an apparent lower capacity for conflict management and relative dearth of such networks.

\subsection{KDP in Kecamatan Proppo, Kabupatan Pamekasan, East Java ${ }^{58}$}

In another case from the village of Tattangoh in the East Java district of Pamekasan, researchers tracked the evolution of a conflict between elites and community members regarding the management of KDP itself. The improvement in the management of KDP in Tattangoh was quite noticeable over its three-year life there. An important piece of this improvement includes the routines

In the first year, nearly all of the most important participatory components of the program failed. Village representation on the kecamatan councils responsible for selecting project proposals was nonexistent, no kecamatan forum was ever held, and villages failed to create even one proposal. Additionally, the kecamatan head appointed a family member as kecamatan facilitator (FK) instead of opening the selection to a transparent election (as mandated by program rules). This FK, in turn, appointed the Tattangoh village-level facilitator for the program (FD), who is responsible for "socializing" villagers into the program, inviting the entire village to meetings, and proactively identifying neighborhood groups to develop proposals. This selection also broke the KDP rule that the FD be elected. Not surprisingly, interviews and focus groups targeted at a broad cross-section of villagers reveal that few even knew the program existed, much less participated in the series of deliberative and planning meetings required by the program. In addition to these miscarried processes, the program's outcomes also revealed a familiar pattern of elite capture in the village: the 750 million rupiah (about $\$ 85,000$ ) allocated to the program flowed directly to drains in a market owned by the village head of Tattangoh. Amidst this overall failure, the use of an anonymous complaints mechanism by an unknown informant led to the FK's dismissal by National Management Consultants, the firm who monitor program implementation and performance.

This last twist in Year 1 epitomizes the turn taken by the program in several KDP villages across Proppo over the next two years. While the routines by which villagers managed the program did not become dramatically more collaborative, incremental improvements in countervailing power began to emerge. As mandated by KDP, villagers held elections for the program's project implementation team (TPK), financial team (UPK), and technical facilitator (TTD). Although not without flaws, villagers also held elections for FD, proposal competitions broadened in their range of participants, and neighborhood-level brainstorming meetings began to convene. Villagers also began participating in the program's consultative meetings (musyawarah). At a minimum, one could safely say that the associational interactions generated within these new

\footnotetext{
${ }^{58}$ Discussion of this case draws heavily on Diprose (2004) and of course, Ashari (2003), the original case study.
} 
institutional structures have the potential to become more formidable bases of countervailing power. Nevertheless, a familiar picture emerges: despite the newly emerged skeletal structures for representation, participants lacked the flesh of countervailing power required to fundamentally revise the overall context of elite dominance in project decision making. Elites tended to dominate decision making processes and the handling of project finances, while the TPK, LKMD, TTD, village heads, UPK, and FK were also involved in small scale corruption.

While the institutions KDP created in Proppo involved broader groups of non-elite villagers in decision-making processes, these villagers nevertheless failed to gain much sustained purchase within these processes. Many who created proposals but failed to obtain funds grew even more disenchanted with what they viewed as a series of elite-dominated processes. They expressed a sense of futility over taking part in the deliberative musyawarah when the same groups seemed to receive funding year after year. As a result these groups reported diminishing interest in the brainstorming and proposal submission process.

\subsection{Land Conflicts in Mangarrai, Nusa Tengarra Timor}

In another case from an area with a tradition of violent land conflicts in the sub-district of Mangarrai in Nusa Tengarra Timor (NTT), we find differing evidence regarding inter-group conflict management routines and systems of power. Tracing back to 1950, this inter-village conflict over a shared land boundary escalated significantly between 1990 and 1999, yielding a series of deaths, injuries, and property destruction. Through an uncommonly successful mediation process conducted over the course of more than a year, a local parish priest managed to gain the trust of the conflicting parties. By building an appreciation for both the technical (historical and geographic) background of the conflict and the contrasting requirements for reconciliation, the priest built the credibility and knowledge required to gradually craft an effective mediation process. Conducting a peace ceremony that combined traditional (adat) and church rites sensitive to the inter-marriage links between the villages, the result was a cessation of violence based around previously unrecognized similarities of ethnic background. The ceremony and mediation process yielded more than just a cessation of violence. After feuding for over fifty years, the groups began emphasizing their shared ethnic roots, both in speech and in patterns of associational interaction with one another. Some analysts would propose that by modelling a repeatable routine of interaction with one another, the mediator helped transform a vicious cycle of violence into a virtuous cycle of thickened associational interaction and discursive emphasis on a previously obscured common identity.

While the evidence does not substantiate this sweeping of a claim, what seems clear from the case is that over the nearly two years of the conflict, both parties developed something more closely resembling an equitable system of countervailing power between themselves. Whereas previous disputes between the farmers featured attempts by each to assert its autarchic and exclusive command over the disputed boundary, the result of their mediated encounters was an agreement predicated on sharing authority over its use. Though confined to their particular dispute, the mediator crafted an overarching meta-rule ${ }^{59}$ or agreement on principle about how to proceed - and particularly about how to express discordant views in a way that considered the authority of the other side - despite their disagreements. Combined with the mediator's intimate

\footnotetext{
${ }^{59}$ See Barron, Smith and Woolcock (2004) for a more detailed discussion of meta-rules.
} 
technical and substantive knowledge of property, boundaries, and highly contextual norms encircling both in Mangarrai, the meta-rule generated a foundation for shared, countervailing power between the farmers and their respective families.

Students of conflict resolution and mediation will rightly note, however, that this scheme of countervailing power was not the product of a purely participatory or collaborative process of exchange between the groups. Rather, as is common in brokered mediations between belligerent groups in international diplomacy ${ }^{60}$ as well as land conflict in eastern Indonesia, resolving intractable conflicts (outside of the purview of a community driven development program like KDP) often requires rigidly hierarchical and top-down routines for managing conflict. Mediators carefully control the sequence of communications between disputing parties, symbolic locations of their meetings ${ }^{61}$, and the agenda of issues that will be discussed in certain contexts. Often this structure and the presence of a neutral party to uphold it becomes the only reason disputing groups set foot in the same room with one another. This rigid but effective control of the process stands in stark contrast to the more adaptable routines which projects like KDP aim to cultivate.

Yet one lesson of this conflict, which applies to the analysis of participatory development projects, is that both rigidly hierarchical and adaptive participatory routines must simultaneously speak in multiple cultural and social languages to generate the new and shared domain of understanding required for a resolution to arise. Credible and knowledgeable mediators often have a pivotal role to play in orchestrating agreements because they may be the only parties able to even recognize the multiple cultural and social dimensions of a conflict, much less craft the correspondingly nuanced approaches required to resolve it. In this and other cases of land conflict in Mangarrai, successful mediators must particularly apprehend and be able to translate the divergent histories of conflict over land - often stretching back over centuries - which underpin each group's identity. Knowledge of this obscure history as well as mastery of the ways of speaking and acting required to legitimately and credibly mediate between more and less powerful groups to reconcile their differences - may not be immediately obvious to one side or another. Especially where many formal and informal social and cultural institutions confer multiple, overlapping layers of meaning - in this case multiple interpretations of ownershiponto the same action, one group may consider that act legitimate while another considers it transgressive. Correspondingly, the work of crafting an overarching process for reconciling these variant ontologies and the conflicts they generate necessarily becomes complex.

In the case of the Mangarrai conflict, the process involved over one year and an idiosyncratic mixture of conferring authorities, including leaders of traditional (adat) law, Catholic parishioners, and government officials from three different levels. The combined effect of the incentives and disincentives leveraged on the parties by this odd mixture proved capable of stopping a vicious cycle of violence, but the eventual strategy never would have been selfevident ex ante because of its complexity. By creating a common language that enraged parties could both speak, mediation started a virtuous cycle of inter-group exchange, characterized by fair access to the ongoing conversation, with neither party feeling excluded. Recognizing each other's different positions, and more profoundly the roots of identity behind those positions, required repeated rhetorical exchanges in terms that both sides could own and uphold. Though

\footnotetext{
${ }^{60}$ Harvard Business School Case \#9-801-393 (2001): George Mitchell and the Northern Ireland Peace Negotiations.

${ }^{61}$ Rao (2004) usefully argues that such deliberative spaces can be called "symbolic public goods."
} 
not a model for programs like KDP, it also required a relatively neutral mediator who could rigidly control and hierarchically organize such exchanges.

\subsection{KDP in Kecamatan Pasean, Kabupatan Pamekasan, East Java}

Assessing the role of KDP in Kecamatan Pasean first requires at least a cursory understanding of dominant social and cultural institutions across the largely Muslim island of Madura, where Pamekasan is located. The study's sampling initially identified Pamekasan as a "low capacity" district with respect to conflict management capacity. Researchers based this estimate upon prefieldwork which suggested higher (relative to similar but high capacity districts) rates of violence as well as more detailed qualitative evidence of violent norms of conflict within traditional Madurese social and cultural institutions. Carok (pronounced cha - rock), for example, is a Madurese tradition of duelling in which male combatants use sickles and often fight to the death, typically following otherwise non-violent verbal altercations in which at least one combatant perceives a blemish on his social reputation. Researchers identified several recent occasions in which carok expanded beyond two combatants to include their family members and culminated in more than just two deaths and often as many as ten. Carok typically arises following verbal conflicts whose chief characteristic is a highly paternalistic, male-dominated routine of adversarial decision making in which women become objects but not subjects of conflict. In these conflicts women lack not only influence but also access to the more and less public forums in which adversaries clash.

Within this localized context of inflamed, male-dominated routines of conflict management, the deliberative processes which KDP introduces quickly become controversial. At a minimum, KDP's requirement that women represent project proposals in sub-district forums that typically draw contentious debate injects women into the center of collective conflicts about scarce resources. Ethnographies of such conflicts in Pasaen note that women often gained greater access to decision making but did not necessarily become active contributers.

“...At the KDP meeting in the MD [Musyawarah Desa - inter-hamlet meeting usually to discuss ideas for development project proposals] there were about 70 women attending. You could say this is quite a lot for a village meeting because women are not usually invited to attend village meetings. Actually it's not really a problem but generally they're embarrassed to attend. Perhaps because that's been the custom here in Madura."

- Female program beneficiary, Desa Sana Daya, Kabupatan Pamekasan, 13 February 2004

Although impossible to empirically verify its direct causes and effects, increased access to decision making within KDP's forums coincide with the rise of decision making routines in which women functioned as subjects, rather than just the passive objects of collective conflicts. Seen in the overarching cultural and social institutional context of gender relations on Madura, merely accessing a collective and inter-gender decision making forum-regardless of developing any observable influence in it-represents a substantial departure over previous norms. Researchers noted, for example, that in Desa Sana Daya one female respondent demanded that her husband be present for the interview. Across Madura, traditional, enforced Islamic norms forbid women from speaking with men unless at least one of the woman's male relatives or husband is present. 
In such a context, encouraging inclusive collective decision making requires interventions that that work within as well as outside of actual forums. This may require highly contextual knowledge on the part of both KDP facilitators and participants, including knowledge of preexisting institutions and the composition of participants. The same female participant reported that:

"Just to get them [women] to attend the Village Forum they had to be given invitations first. The village head invited them by going around each of the dusun [hamlet] meetings. The FD [KDP village facilitator] had also told them about the meetings in their Koran Recital Groups.”

- Female program beneficiary, Desa Sana Daya, Kabupatan Pamekasan, 13 February 2004

This suggests that how KDP functionaries organize the invitation of women - or indeed any member of a socially marginalized group - to forums ultimately shapes the likelihood that they will attend and influence decisions. In Sana Daya both the KDP village facilitator and the village head invited women in neighbourhood meetings as well as in religious forums. The finding that this combined approach coincided with relatively high numbers of women raises the unanswered question of whether the overtures of the village head, the FD, both, or neither ultimately contributed to the increased attendance of women. A separate finding from a recent randomized experiment showed that sending KDP invitations home with school children (as opposed to merely allowing village heads to invite whomever they choose) increased the likelihood of marginalized groups attending forums. ${ }^{62}$ The researcher theorized that this approach increased the number of women who attended because children are more likely to give the invitations to their mothers, as the traditionally care-giver, than to fathers.

Partly because the Sana Daya FD hailed from outside of Madura (KDP facilitators often enter program contexts as geographic outsiders), the ramifications of working in tandem with the village head - both in distributing invitations and in other elements of KDP's implementationleaves room for multiple interpretations. On the one hand, involving the village head in this way risked reinforcing pre-existing village-level hierarchies in a program which intends to redistribute power more equitably. On the other hand, working with the village head may have also diffused participants' impression that facilitators are outsiders meddling with Madura's localized Islamic norms. Although the relative isolation of Sana Daya from the influence of nonMadurese norms lends more credence to the latter explanation, the larger salient point seems to be that disseminating invitations through several types of elite and non-elite social institutions may yield more inclusive KDP forums than invitations extended through just one channel.

Thus the efficacy (and lack of efficacy) of KDP in Pasaen villages such as Sana Daya might be considered along two horizons. First, KDP rendered the accepted routines for managing conflict less rigidly hierarchical and adversarial by broadening the composition of identity groups that attended its forums. When functioning properly, KDP rules codified the legitimate presence of women as some of the parties to a public controversy about public resource allocation. Yet the reasons that no women actually influenced decision making are much more complex and have to do with the depth as well as the breadth of conflicts between more and less powerful groups. One seems to be that if KDP introduced new routines of conflict management, those routines never became vigorously collaborative or participatory enough to creatively lower outsiders'

\footnotetext{
${ }^{62}$ Olken (2004)
} 
social costs of contributing original input. In a context in which women generally occupy domestic roles, real-life threats to their social status accompany any attempt to influence the domains of decision making typically reserved for elite men. Though contingent on many highly contextual factors (many of them unobservable), the kinds of collaborative routines that lower these costs rely on more than just functioning program rules. Ultimately, high quality facilitators must create the open and accessible communicative spaces that marginalized parties need to overcome their defining rhetorical disadvantages, lack of agenda setting ability, and deficient experience organizing their interests in ways that elites must respond to.

A second horizon for assessing KDP's efficacy - the types of collective inter-group power relationships it cultivates in practice-may at first seem an inappropriate parameter of comparison since even KDP's most fervent supporters consider its role in social development to be piecemeal and limited at best. Nevertheless, the data spells out unmistakable differences in the kinds of spaces, incentives, and resources for conflict management that KDP simultaneously responds to and shapes on local levels. Because collaborative institutions of the type that KDP hopes to foster ultimately grow from endogenous political processes, different groups come to KDP with broad differences in their organization and concentration of their interests. The case of Sana Daya is a familiar one: even KDP's collaborative rules mandating broad participation were not enough to splinter the autarchic power held by a relatively small but adversarially organized group of elite males with highly concentrated and entrenched interests. These adversarial tactics included narrowing the agenda of issues open to collaboration, restricting the actual functioning of collaboration to the development of easily ignored advice (rather than imperatives), and practically limiting the role of outside participants to impartial observers (rather than influential contributors).

Still, in the broader context of a village and region in which weak police and court systems coexist with violent conflict management norms such as carok, the contributions of KDP seem slightly more substantial. In such a tinderbox, the very fact that KDP led to neither physical violence nor significant property destruction - even though it introduced a competitive proposal development/lobbying process and a sequence of heated decision making forums that sparked sharp conflict within and between groups - seems remarkable. Even where the program failed to build more countervailing rather than more autarchic group centers of power, respondents suggest that more broadly accessible forums for expressing disagreement, together with anonymous, accountable complaints mechanisms ultimately made resisting the dominance of one powerful group easier. Even though KDP did not yield the happy combination of collaborative routines and countervailing power which characterizes adaptive problem solving, these findings

of its incremental progress toward both represent a nontrivial outcome for a development program.

\subsection{Other Cases}

Worth noting is our finding that many cases featured two or more similarly marginalized actors battling against one another rather than against more organized or established interests. Whereas the dam case featured more and less powerful groups in conflict with one another, some of the 
most tragic cases of conflict in our data (including carok $^{63}$ cases) are those in which two similarly marginalized groups find themselves trapped in cycles of violence and retribution. Many of our cases from Sikka and Mangarrai-areas in which the per capita GDPs of subdistrict approach US\$200 - fall into this category. Often parties in such conflicts are both similarly isolated from economic, political, social, and even cultural power, yet find themselves clashing over the only available resource for survival: land, water, and life itself. In such cases, a slightly more nuanced view of empowerment, which we don't address here, is necessary and may include peacekeeping missions and policing. In such instances, intermediaries sometimes take more forceful shapes, for example police interventions to stop village level violence in Indonesia's Maluku province or military interventions in Aceh to stop senseless bloodshed. Thus, routines for immediately stopping violence need not necessarily be collaborative nor must types of power be countervailing in order to be salient for development. These cases of larger scale violence, however, go beyond the scope of this paper.

\section{Analysis and Implications}

\subsection{Routines}

Our cases suggest that the routines associated with different approaches to conflict management matter to the development of countervailing power in at least three ways. First, routines accompanying formal and informal conflict management institutions shape the actors of intraand inter-group problem solving and decision-making. By (often implicitly) influencing which party and/or mediator has authority (in the case of two party negotiations) or jurisdiction (in the case of mediation), routines necessarily reify the inter-group power distributions that permeate initial attempts (as well as ongoing ones, in many cases) at resolution.

But not all routines are created equal. One type determines authorities and jurisdictions by borrowing directly from the hierarchies and stereotyped roles of society and culture. An example concerns the routines commonly (although not universally) associated with traditional adat forums in Sikka. When conflicts invoke theses forums for mediation of domestic violence disputes, the authoritative mediators selected are generally groups of socially and culturally elite males. Not surprisingly, the routines followed a rigidly top-down and adversarial meeting out of justice that only perpetuated the exclusion and suffering of victims.

Another type of routine, however, shapes the agents of conflict resolution through a more piecemeal re-ordering of dominant roles and hierarchies. Conflicts featuring forums with more diverse inter-group associational ties correspondingly end up with arbiters who are less entrenched at the top of social and cultural hierarchies. In the Sumorobangun Dam case, the routine that the farmers' coalition followed-using public protests and acts of civil disobedience such as blocking traffic across bridges-established themselves as legitimate authorities for resolving the conflict. By successfully demanding accountability from the district authorities responsible for maintaining the dam, the farmers group established themselves as essential participants in the conflict, a powerful, united player to be reckoned with. Another key feature

\footnotetext{
${ }^{63}$ Carok is a Madurese tradition of dueling and sometimes mass combat, in which combatants use sickles and often fight to the death.
} 
of their strategy was prioritizing an interest and then building an alliance around that interest. As opposed to permitting pre-existing group loyalties to determine their interests, this strategy of prescriptively generating associations to pursue constructive interests is perhaps the most fundamental definition of empowerment. By broadening its coalition to include an array of poor and relatively rich parties (especially land owners), the group maximized its countervailing power.

Similarly, within KDP, context-revising routines flourished where rules were upheld for the election of key project team members, where open consultation and deliberation were embraced in forums, and where collaborative competition was pursued in proposal selection. This ties into a second quality of routines: they shape processes of intra- and inter-group problem solving. In one sense, routines are discursive; they are implicit guidelines about how to talk and act when disagreements arise. As such, they shape a wide range of negotiation processes that confer some groups with more power than others. For example, in the Ponorogo dam case, a coalition of farmers used symbols of resistance and public performance that elicited accountability from elite, district-level decision makers. The climax of their protests was a highly symbolic demonstration in which the coalition placed two empty chairs facing a dilapidated bridge and demanded that the two district officials responsible for its maintenance visibly take account of its poor condition. In the midst of failure of the formal rules for holding district officials accountable for this common pool resource, this richly symbolic routine became a powerful practice by which the coalition fundamentally changed the way it "got recognized" by elites, to borrow Appadurai's language. Using an integrative strategy which forcibly aligned their interests with those of district-officials seeking re-election, the farmers coalition created a process which increased their power where previously they had little or no voice. ${ }^{64}$

A third quality of conflict management routines involves the underlying motivations for problem solving. The motivations that opposing groups have for starting a conflict and the motivations they have for ending it may differ greatly. For example, in some conflicts it is unrealistic to expect that groups with a history of violence develop longstanding resolutions over the course of a conflict. Rather, they may simply seek a cessation of violence. This is especially common in cases in which two very poor and marginalized groups clash with one another over scarce common pool resources, such as land or water. Where less powerful groups clash with more powerful groups over a particular issue - as in the case of the Sumorangum Dam - more value may be at stake and available for transfer between parties. In such cases, marginalized parties in particular may have an incentive to craft resolutions. On the other hand, more powerful groups may simply have no incentive to end conflict because they benefit from it. One example is our set of cases in which village level vigilante "enforcers" profit from "witch-hunts" of villagers commonly believed to have placed curses on other dead or dying villagers. Because they benefit financially from bidding up the price paid to them for either killing or saving the witch, they have a vested interest in perpetuating the conflict and often conspire to drag it out. Such

\footnotetext{
${ }^{64}$ We borrow "integrative bargaining" from the literature on negotiation analysis. See especially Fischer and Ury (1994), who define it as logrolling or a strategy of trading on mutually beneficial differences in interests. Here, we note that this victory by the coalition did not unambiguously advance their interests, while purely diminishing those of district officials. District officials coalesced to their demands partly because of the support they garnered in a future election. In Heifetz's terms, both groups "used and abused" each other and both groups ended up with more power because of the routine used by the farmers' coalition.
} 
incentives and disincentives correspondingly shape the types of routines used by groups in conflict.

\subsection{Countervailing versus Autarchic Power}

As suggested by a long line of anthropological research associated with Geertz and Horowitz, our ethnographies of local level conflict show that power is as much about generating shared meanings in a particular context of social and cultural norms and institutions than it is anything else. Lacking influence involves a vicious cycle: those unable to purposefully navigate in shared worlds of meaning-making are precisely those who lack the opportunities for the kinds of conjecture, refutation, inquiry, and criticism, which might result in greater influence. Said differently, marginalization is about lacking both the capability and the occasions on which to engage in productive conflict. With this debt, marginalized actors struggle to "get recognized" in these contexts and tend to oscillate between intense "loyalty" to core cultural values and "exit" from them, often manifest in violent protest or total apathy (Hirschman 1970, Appadurai 2004). Finding the middle ground amidst these two extremes typically involves negotiating meta-rules, intermediaries, and approaches to interest formation and defense, all of which make the prospect of finding resolutions to conflict more palpable. ${ }^{65}$

But even adaptive conflict management routines - within or outside of KDP processes - are insufficient to reach the poorest of the poor. The most troubled need the most help to develop the countervailing power to challenge dominant norms of communication. Here, small experiments suggest that such efforts need to speak in deeply symbolic cultural and social languages to become actions of resistance. A small KDP pilot program that targets widows in four provinces provides a good example. Run by an NGO, the program helps organize widows by organizing them to the point that they can collectively rejoin group decision-making. ${ }^{66} \mathrm{~A}$ major tool it uses is training in documentary photography, which some participants have used to express a range of sensations and impressions of village life. Such targeted attempts are in many ways the missing link to a more comprehensive empowerment strategy because they complement the program's deliberative spaces and incentives for inter-group collaboration with tools for intra-group mobilization. Without such a tool for lowering otherwise high opportunity costs of collaboration, marginalized groups find little incentive to participate in deliberative forums, project planning, or in the project more generally.

Part of what this demonstrates is that broad, far-reaching collaboration may require marginalized groups to find new ways of speaking and acting outside of inter-group collaborations. While KDP proposes that villagers learn about democracy by practicing it, its most marginalized participants may need more practice outside of the program. That practice, moreover, may come in surprisingly creative forms that speak highly contextualized and often personal languages of context revision. This should all confirm that countervailing power and context-revision do not refer to the unrealistic notion that institutions rise and fall monolithically and suddenly. Rather, revision is incremental and gradual, and may mirror what the psychological literature calls "small wins" (Weick 1984) and the legal institutional literature calls "small steps" (Sunstein and Ullmann-Margalit 1998). In short, context-revising routines of collaboration may become most

\footnotetext{
${ }^{65}$ See Barron, Smith, and Woolcock (2004).

${ }^{66}$ Guggenheim (2004: 30).
} 
embedded when marginalized groups can develop means of countervailing power in their own personal lives or immediate social groups. Thus the question of sources for countervailing power is very much an open one, with neither a verifiable nor a consistent answer across different contexts. However, the cases suggest at least three potential sources: KDP itself, members of minority political parties, issue oriented mobilization groups, and innovative experiments such as the widows' pilot project.

More generally, however, our data suggest that adaptive conflict management is a form of collaboration that relies at least partly on the presence of countervailing power. The sources of countervailing power seem to be quite capricious, arising from the diffuse public sphere to crystallize in the more familiar forms of interest groups, social movements, and lower barriers to collective action. ${ }^{67}$ Nevertheless, there is some evidence in well-functioning KDP villages that countervailing power seems to be on the rise. One crude but revealing measure of this apparent trend in village from Ponorogo includes the number and identity of people who participated in KDP forums. In our cases, for example, two and sometimes three main elite coalitions tended to fight about public decision-making in KDP areas, whereas in non-KDP areas elites seemed to be more monolithic. Far from suggesting the formation of robust alliances of everyday villagers, this trend indicates that elites may be splintering into more and smaller groups because of the increased involvement of everyday villagers. In a survey given to key informants in Ponorogo, a majority reported that village decision-making and conflict resolution had become at least somewhat more democratic since KDP's implementation. ${ }^{68}$ Perhaps more telling is one woman's comment from an in depth interview: "Women have only just started to want to come together (in meetings) since KDP...Women were unwilling [to attend meetings for another development project] because...there was a cynical view of women who attended meetings in the village hall...But since KDP, women's participation has improved." ${ }^{\text {, } 99}$

\subsection{Disaggregating Conflict Management}

In the cases above, actors from marginalized groups typically succeeded either in developing sources of countervailing power or in developing collaborative decision-making routines. But rarely did they achieve both. We might then place the cases into three stylized categories. The first category concerns cases in which marginalized groups developed countervailing power, but lacked sustained collaborative routines. In the Sumorabangun Case, for example, the network of associational ties which mobilized around a protest act represented an ephemeral but formidable check on the otherwise dominant power of district and regional officials in charge of managing that public resource. Yet, without a formalized system of collaborative routines for embedding their cooperation, the network of protesters achieved little staying power. When faced with the reality of navigating within an adversarial, top down public institutions, their coalition and its tactics ultimately proved unsustainable and lost its momentary influence. Though impossible to say definitively, KDP in Biting village and other villages surrounding the dam could have generated some of the associational ties that formed the core of episodic mobilization around the dam. What seems more certain is that without a functional set of collaborative routines in which

\footnotetext{
${ }^{67}$ Fung (2002)

${ }^{68}$ These results are not statistically significant; see Rasyid (2004).

${ }^{69}$ Rasyid (2004)
} 
to parlay their countervailing power, the coalition quickly became latent without a focusing event for working together.

The second category accounts for a much larger share of the cases: those in which marginalized groups had moderate success in promoting routines of collaboration but could develop little in the way of countervailing power required to stave off elite domination of decision-making processes. Such was the fate of KDP in Kecamatan Proppo, where brainstorming processes, proposal creation, and inclusive facilitation all improved over the three years of the project. Ultimately, however, without an adequately substantial point of strength from which to draw out the collaboration rather than domination of elites, actors from marginalized groups gained little sustainable influence over decision-making processes. On one hand, it is a nontrivial finding that anonymous complaints mechanisms within KDP gave everyday villagers a means to demand accountability from elites (and indeed the replacement of some) who had captured key KDP positions early in the program by circumventing the elections requirement. Nevertheless, these negative complaints tools proved insufficient for them to positively sustain the coalition of countervailing power required to stimulate collaboration by elites rather than continued domination of decision-making and project implementation.

The third, most unfavorable category involves cases where marginalized groups neither won support for collaborative routines nor acquired a substantial or sustainable basis of countervailing power. These are generally characterized by extreme situations of elite capture. A fourth logical possibility, but practical rarity, is the situation of highly collaborative routines of conflict management matched by well organized countervailing power. In the next section we discuss empowerment as a series of transitions between the categories.

\subsection{Empowerment as Catalyzing Peaceful Transitions}

A central finding of this paper is that empowerment for marginalized groups in conflict situations involves making transitions both in the nature of forums (or opportunity structures) used for deciding conflicts, as well as in the types of power (or agency) used to acquire legitimacy in such forums. ${ }^{70}$ Table 1 below provides a stylized representation of the range of conflict management routines which various combinations of the two can generate. It locates the intended and actual contributions of KDP's treatments as well as the crucial general circumstances surrounding village level decision making within this matrix.

A key characteristic of KDP is the provision of forums for managing the conflict the project necessarily introduces through competition over finite resources. But even relatively well functioning KDP forums, which are witness to multiple face-to-face encounters between groups who may never otherwise formally interact with one another, may still create power vacuums.

\footnotetext{
${ }^{70}$ It is in this direct sense, that our paper speaks to the broader Measuring Empowerment framework of which this study is a part. Our findings suggest that, in terms of opportunity structure, the key task for development projects is to create the spaces, resources, and incentives that enable the poor to build effective and durable bases of countervailing power in those realms where decisions most immediately pertaining to their welfare are made; in terms of agency, the primary challenge is enhancing the capacities to aspire and (perhaps more importantly) engage - that is, helping marginalized groups to be able to conceive of and enact alternative futures using modalities of exchange, refutation, and dialogue ("discursive routines") in which they have a comparative advantage as a basis for more confidently and effectively negotiating their entry into broader political spaces.
} 
This all too common situation, well known to theorists of collective action failure, is represented in Box II below. Box II represents forums that systematically exclude already marginalized groups and which feature adversarial sets of politics and domination of decision-making by one or a few groups which exercise autarchic decision making power. Perhaps the situation of least power for marginalized groups, Box II represents both the lack of collaborative forums as well as the lack of countervailing power. Box I is marginally more empowering in that groups exert a small measure of informal, often disruptive power in political and social institutions. (Here examples include labor strikes by mine workers in Ponorogo). Partly because of the lack of adequately prepared organizations and similar problems of coordination between the poor, these examples throughout the data brought few tangible gains to marginalized groups.

Table 1: Routines for Managing Local Conflict

\begin{tabular}{|c|c|c|c|}
\hline \multirow{4}{*}{ 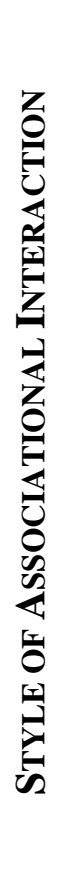 } & & \multicolumn{2}{|c|}{ TYPES OF POWER } \\
\hline & & AUTARCHIC & COUNTERVAILING \\
\hline & $\begin{array}{l}\text { TOP-DOWN, } \\
\text { ADVERSARIAL }\end{array}$ & $\begin{array}{l}\text { II. Elite Capture } \\
\text { "Corruption, Collusion, } \\
\text { Nepotism" } \\
\text {-KDP Year } 1 \text { Kecamatan } \\
\text { Proppo, EJ } \\
\text {-Many Examples }\end{array}$ & $\begin{array}{l}\text { I. Interest Group Politics } \\
\text { Elected or appointed interest } \\
\text { groups forced (often by election } \\
\text { cycles) into giving patronage to } \\
\text { marginalized groups which may } \\
\text { acquire interest group status } \\
\text { Ponorogo Dam Case }\end{array}$ \\
\hline & $\begin{array}{l}\text { PARTICIPATORY, } \\
\text { COLLABORATIVE }\end{array}$ & $\begin{array}{l}\text { III. Access, Little or no } \\
\text { Influence } \\
\text { - Poorly functioning KDP } \\
\text { forums: marginalized groups } \\
\text { have seat at table, but generate } \\
\text { no inducement for elites to } \\
\text { collaborate; elites dominate } \\
\text { forums via agenda- } \\
\text { setting/limiting, participant } \\
\text { restriction, reduction of inputs } \\
\text { to ignorable advice } \\
\text { - KDP Year 2, Proppo }\end{array}$ & $\begin{array}{l}\text { IV. Adaptive Problem Solving } \\
\text { - Well-functioning KDP forums: } \\
\text { marginalized groups maximize } \\
\text { their seat at the table by } \\
\text { combining: (a) public displays of } \\
\text { their strength outside of } \\
\text { collaborative forums (via } \\
\text { adversarial organizations, political } \\
\text { parties) with (b) context-revising } \\
\text { discursive and practical routines } \\
\text { within such forums resulting in } \\
\text { "adaptive" problem-solving } \\
\text { - Few examples }\end{array}$ \\
\hline
\end{tabular}

The entrance of KDP onto the scene often helps marginalized groups make the transition from Box II to Box III, but rarely to Box IV. Nevertheless, the movement to Box III implies a small measure of empowerment because groups that were previously excluded from the formal seats of decision-making for development projects and microfinance activities ostensibly acquire an entré. The lack of countervailing power here can arise for many reasons including three directly related to KDP. First, intermediaries - in the form of facilitators - may do an inadequate job of including groups in discussions or may not ensure that invitations are broadly disseminated. Similarly, standard KDP procedures - for instance posting prices of material for construction projects in visible, public places and announcing them at KDP meetings-may simply not happen. Secondly, the meta-rules KDP introduces may be patently unfair where they place a premium on relatively sophisticated discursive and practical routines which women and the poorest may never have developed due to sickness, lack of time, and/or lack of education. Again where it functions well, KDP should divide technical work that requires accounting practices and technical skill (in construction, for example) among respective committees, while finding uses 
for the particular skills of less educated and less able villagers in other committees and roles. This may also result in a sense among participants that potential benefits of participation do not warrant the time and energy required to participate. Thirdly, the ways in which groups (their leaders, and constituent individuals) interact with each other and define, defend, and reconstruct their identity - or, more accurately, particular forms of identity in response to particular circumstances-ultimately shapes the power of groups. ${ }^{71}$ For example, norms of decisionmaking in KDP forums may militate against women, the poor, and individuals from certain cultural traditions. Where these individuals are not encouraged to participate, the (il)logic of their membership in a particular identity group may preclude quick involvement in a novel associational setting. Such problems are well known to facilitators of participatory processes in developing and industrialized nations alike.

Thus another key question is whether-in addition to providing inclusive decision-making forums - such participatory collaborative processes can help generate such points of strength for coalitions of marginalized groups to develop countervailing power, and if so, how? Does KDP in fact empower villagers in this way? We argue that KDP can over time, but the initial stage of this brand of empowerment may be neither flashy nor definitive in their observable implications. Our case studies do suggest that typically KDP forums catalyzed formal associational interactions and sustained deliberation between diverse groups of women and the poor who may otherwise have found no reason to interact with one another. Key informant surveys from wellfunctioning KDP districts reveal that villagers find its deliberative forums more democratic than most other forums in their villages. ${ }^{72}$ In addition to these findings, a good indicator of empowerment is whether or not KDP provides forums for the management of the conflict it necessarily introduces to villages and neighborhoods. By this measure, it does exceptionally well. In none of our case studies did we find evidence that conflicts caused by KDP forums (for example, competition between neighborhood groups vying for the ability to submit funding proposals to the sub-district forum) went unresolved or became violent. The fact that the program provides and encourages a series of routines for allocating the time, resources, and spaces required to peacefully resolve the conflicts it inevitably introduces is an achievement in and of itself.

\section{Conclusion}

KDP in Indonesia represents a very self-conscious movement away from the notion of development agencies as the deliverer of "the project" and toward a vision of development projects as ways to trigger and support processes in which villagers exercise discretion in solving self-identified development problems. ${ }^{73}$ Thus, a natural and indeed purposeful product of this approach is conflict. But beyond simply inducing conflict in this way, we have argued that KDP also cultivates a set of collaborative routines of conflict management that villagers can use to interface with more organized and influential actors. Within sets of facilitated forums extending from neighborhood to village to sub-district levels, the simple act of participating in KDP planning and decision making forums often becomes the first occasion in which villagers from

\footnotetext{
${ }^{71}$ Diprose (2003) and Barron, Smith, and Woolcock (2004) develop this notion as the "dynamics of difference."

${ }^{72}$ Clark, Marwardi, and Barron (2004)

${ }^{73}$ Guggenheim (forthcoming)
} 
different identity groups congregate around purposeful collective action and decision making. The willingness and ability of external agents to introduce new resources into communities, along with deliberative and administrative tools for managing the inevitable conflict which arise over them, in many respects represents a radical departure in the development practice (if not theory), at least for large multi- and bi-lateral agencies.

Clearly, however, KDP is not without its flaws. Especially where the most disenfranchised villagers are concerned, building this brand of conflict management capacity — and ultimately empowerment - depends on more than just collaborative routines and deliberation. The presence of countervailing power among the poor is both a product of, and breathes life into, deliberative spaces and attempts by the poor to influence decision-making. As such, conflicts often ariseboth within and outside of KDP process - in which marginalized groups lack and cannot develop ways of speaking and acting that prevent elites from dominating decision making using adversarial tactics. Yet in otherwise dark scenarios of elite capture, the data suggest that anonymous complaint mechanisms and other accountability measures within the program allow those cut out of decision making to "defensively" express their voices. In more than one case, those using this kind of recourse initiated a slow broadening of involvement and lessening of elite capture (e.g., the reinstatement of elections where previously they had been illegally skipped). In a country whose village level institutions are still emerging from underneath the decades-long shadow of national and district-level political hegemony over neighborhood and village level decision making, ${ }^{74}$ this is no small achievement. Nevertheless, the challenge of providing resources, spaces, and incentives for more positive intra-group countervailing power will always remain for any development project.

Where KDP cultivates conflicts featuring both collaboration and tangible points of political power for marginalized groups, the result is as much a style of solidarity in group interest definition and defense as it is a well-functioning school or medical clinic. We argue that the beginning stage of such a transformation - in which unequal groups build the capability to peacefully engage one another in conflict-is a humble but nontrivial outcome for a development project, especially where violence has been a more normal occurrence. Furthermore, deliberation and shared inter-group decision making have been followed in the data by incremental steps toward more equitable zones of engagement between more and less organized and influential actors. Where development projects refuse to mistake smallness with irrelevance and incrementalism with grandiosity, they might just provide the heat along with the bright light surrounding popular notions of local level empowerment.

${ }^{74}$ Ibid. 


\section{References}

Alatas, Vivi, Lant Pritchett, and Anna Wetterberg (2003). "Voice Lessons: Local Government Organizations, Social Organizations, and the Quality of Local Governance.” World Bank Policy Research Working Paper 2981.

Alsop, Ruth, Nina Heinsohn, and Abby Somma (2003). "Measuring Empowerment: An Analytic Framework." http://nweb18.worldbank.org/ESSD/sdvext.nsf/68ByDocName/CurrentInitiativesMeasuringEm powermentStudy.

Appadurai, Arjun (2004). "The Capacity to Aspire: Culture and the Terms of Recognition." In Vijayendra Rao and Michael Walton (eds.), Culture and Public Action. Stanford: Stanford University Press, pp. 59-84.

Barron, Patrick, Samuel Clark and Ambar Mawardi (2005). "The Links between KDP and Local Conflict: Results from a Key Informant Survey in East Java and NTT.” Mimeo, World Bank, Jakarta.

Barron, Patrick and David Madden (2004). "Violent Conflict in 'Non-Conflict' Regions: The Case of Lampung, Indonesia." East Asia and Pacific Region, Working Paper. Washington, D.C.: World Bank.

Barron, Patrick, Rachael Diprose, Claire Q. Smith, Katherine Whiteside and Michael Woolcock (2004). "Applying Mixed Methods Research to a Community Driven Development Projects and Local Conflict Mediation: A Case Study from Indonesia." March 2. Available at: www.conflictanddevelopment.org

Barron, Patrick, Rachael Diprose, and Michael Woolcock (2005). "Local Conflict and Community Development in Indonesia: Assessing the Impact of the Kecamatan Development Program” World Bank, Jakarta. Mimeo.

Barron, Patrick, Claire Q. Smith, and Michael Woolcock (2004). "Understanding Local Level Conflict Pathways in Developing Countries: Theory, Evidence, and Implications from Indonesia." Working Paper No. 19, Conflict Prevention and Reconstruction Unit, World Bank.

Barron, Patrick, Rachael Diprose, David Madden, Claire Q. Smith, and Michael Woolcock (2004). "Do Participatory Development Projects Help Villagers Manage Local Level Conflicts? A Mixed Methods Approach to Assessing the Kecamatan Development Project, Indonesia." Conflict Prevention and Reconstruction Unit Working Paper No. 9, Washington, D.C.: World Bank

Bourdieu, Pierre (1986). "The Forms of Capital." In John G. Richardson (ed.) Handbook of Theory and Research for the Sociology of Education. New York: Greenwood Press. 
Briggs, Xavier de Sousa (2002). "Community Building: The New (and Old) Politics of Urban Problem-Solving," John F. Kennedy School of Government Working Paper RWP02-003. Harvard University: Cambridge, MA.

Diprose, Rachael. (2003). "The Dynamics of Difference: Contested Identity at the Local Level" World Bank, Jakarta. Mimeo.

Diprose, Rachael (forthcoming). "Conflict Pathways in Indonesia: Conflict, Violence, and Development in East Java.” World Bank, Jakarta. Mimeo.

Evans, Peter (2002). "Collective Capabilities, Culture and Amartya Sen's Development as Freedom." Studies in Comparative International Development 37(2): 54-60.

Evans, Peter (2004). "Development as Institutional Change: The Pitfalls of Monocropping and the Potentials of Deliberation." Studies in Comparative International Development 38(4): 30-52.

Fukuyama, Francis (2004). State-Building: Governance and World Order in the Twenty-First Century. Ithaca, NY: Cornell University Press.

Fung, Archon (2002). Collaboration and Countervailing Power: Making Participatory Governance Work. www.archonfung.net.

Fung, Archon (2003). "Associations and Democracy: Between Theories, Hopes, and Realities." Annual Review of Sociology 29: 515-39.

Fung, Archon and Erik Wright (2003). Deepening Democracy: Institutional Innovations in Empowered Participatory Governance. London: Verso.

Galbraith, John Kenneth (1956). American Capitalism: The Concept of Countervailing Power. New York: Houghton Mifflin.

Geertz, Clifford (1977). The Interpretation of Culture. New York: Perseus.

George, Alexander and Andrew Bennett (2005). Case Studies and Theory Development in the Social Sciences. Cambridge, MA: MIT Press.

Gillespie, Stuart (2004) "Scaling Up Community-Driven Development: A Synthesis of Experience." FCND Discussion Paper No. 181. International Food Policy Research Institute, Washington, D.C.

Guggenheim, Scott E. (forthcoming). "The Kecamatan Development Program, Indonesia." in Anthony Bebbington, Scott E. Guggenheim, Elisabeth Olson, and Michael Woolcock (eds.) The Search for Empowerment: Social Capital as Idea and Practice at the World Bank. Bloomfield, CT: Kumarian Press. 
Harvard Business School Case \# 9-801-393 (2001). “'To Hell with the Future, Let's Get on with the Past': George Mitchell in Northern Ireland." Cambridge, MA: President and Fellows of Harvard College.

Heifetz, Ronald (1994). Leadership Without Easy Answers. Cambridge, MA: Harvard University Press.

Hirschman, Albert (1970). Exit, Voice, and Loyalty: Responses to Decline in Firms, Organizations, and States. Cambridge, MA: Harvard University Press.

Horowitz, Donald (1985). Ethnic Groups in Conflict. Berkeley: University of California Press.

Kabeer, Naila (1999). "Resources, Agency, Achievements: Reflections on the Measurement of Women's Empowerment." Development and Change 30(3): 435-464.

KDP National Secretariat and National Management Consultants (2003). Indonesia: Kecamatan Development Program. December.

Mansuri, Ghazala and Vijayendra Rao (2004). "Community-Based (and Driven) Development: A Critical Review." World Bank Research Observer 19(1):1-39.

McAdam, Douglas, Tarrow, Sidney, and Tilly, Charles (2001). Dynamics of Contention. New York: Cambridge University Press.

Narayan, Deepa (ed.) (2005). Measuring Empowerment: Cross-Disciplinary Perspectives. Washington, D.C.: World Bank.

Nussbaum, Martha (2000). Women and Human Development: The Capabilities Approach. Cambridge: Cambridge University Press.

Olson, Mancur (1965). The Logic of Collective Action: Public Goods and the Theory of Groups. Cambridge: Harvard University Press.

Petesch, Patti, Catalina Smulovitz and Michael Walton (2005). "Evaluating Empowerment: A Framework with Cases from Latin America", in Deepa Narayan (ed.) Measuring Empowerment: Cross-Disciplinary Perspectives. Washington, D.C.: World Bank, pp. 39-67.

Piven, Francis Fox and Cloward, Richard (1977). Poor People's Movements: Why They Succeed and How They Fail. New York: Pantheon Press.

Pritchett, Lant and Michael Woolcock (2004). "Solutions When the Solution is the Problem." World Development 32(2): 191-212.

Probo, Endro (2003). "The Phenomenon of the Martial Arts Schools in Kabupatan Ponorogo." World Bank, Jakarta. Mimeo. 
Putnam, Robert (2000). Bowling Alone: The Collapse and Revival of American Community. New York: Simon and Schuster.

Rao, Vijayendra (2004). "Symbolic Public Goods and the Coordination of Collective Action: A Comparison of Local Development in India and Indonesia," in Pranab Bardhan and Isha Ray (eds.) Conversations between Economists and Anthropologists (forthcoming).

Rao, Vijayendra and Michael Walton (2004). "Culture and Public Action: Relationality, Equality of Agency, and Development." in Vijayendra Rao and Michael Walton (eds.) Culture and Public Action. Stanford: Stanford University Press, pp. 3-36.

Rasyid, Imron (2004). "KDP Implementation and its Spillover Effects on the Lives of the Villagers in Ponorogo: Key Informant Survey Data." Mimeo.

Ray, Debraj (2003). “Aspirations, Poverty and Economic Change". Mimeo, Department of Economics, New York University. Available at: http://www.econ.nyu.edu/user/debraj/.

Scott, James (1985). Weapons of the Weak: Everyday Forms of Peasant Resistance. New Haven: Yale University Press.

Scott, James (1998). Seeing Like a State: How Certain Schemes to Improve the Human Condition Have Failed. New Haven: Yale University Press.

Sen, Amartya (1999). Development as Freedom. New York: Random House.

Sunstein, Cass R. and Ullmann-Margalit, Edna (1999). "Second-order Decisions.” Ethics 110(1): $5-31$.

Unger, Roberto Mangabeira (1998). Democracy Realized. Verso: New York.

Varshney, Ashutosh (2002). Ethnic Conflict and Civic Life: Hindus and Muslims in India. New Haven: Yale University Press.

Weick, Karl E. (1984). "Small Wins: Redefining the Scale of Social Problems." American Psychologist 39(1): 40-49.

Whiteside, Katherine, Michael Woolcock, and Xavier de Sousa Briggs (2005). "Assessing Social Development Projects: Integrating the Art of Practice and the Science of Evaluation." World Bank, Development Research Group, mimeo.

Wittgenstein, Ludwig (2002). Philosophical Investigations: The German Text with a Revised English Translation. New York: Blackwell.

Wolf, Eric R. (1999). Envisioning Power: Ideologies of Dominance and Crisis. Berkeley and Los Angeles: University of California Press. 
World Bank (2000). World Development Report 2000/01: Attacking Poverty. New York: Oxford University Press.

World Bank (2002). Empowerment and Poverty Reduction: A Sourcebook. Washington, D.C. 